\title{
EVALUATION OF THE DIRECT FILTRATION UNDER THE EGYPTIAN CONDITIONS
}

Dr. Anmed Fadel

Civil Eng. Dept.

Faculty of Eng.

El-Mansoura Univ.
Eng. Hesham K. El-Etriby

Civil Eng. Depr.

Faculty of Eng.

E)-Mansoura Univ.

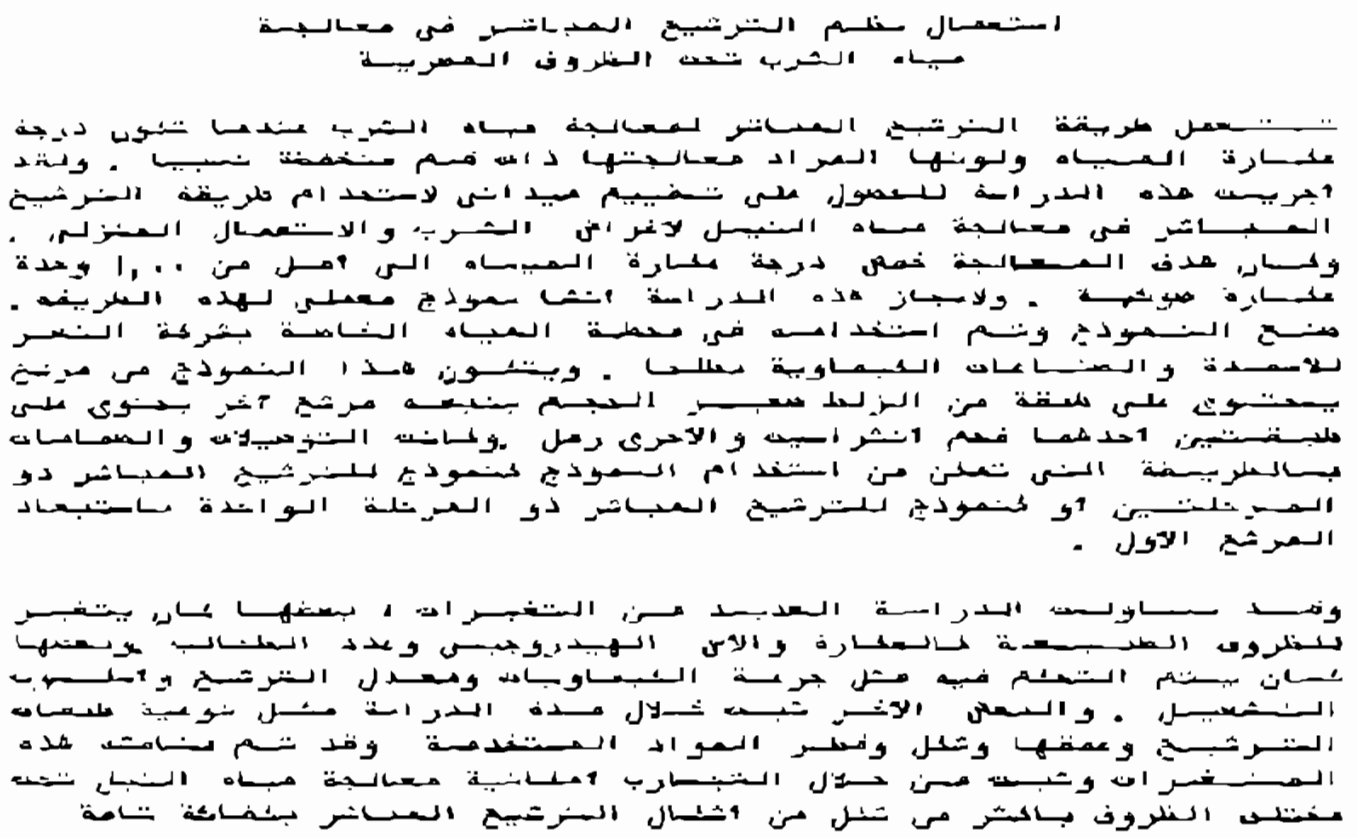

\section{ABSTRACT}

Dicect Eiltration system has been employed as alternative to the conventional coagulation-flocculation-sedimentation-filtration system for treating surface water. The major advantage ol a direct filtration plant over a conventional treatment plant is a capital cost savings of approximately 20-30 percent.

This study was conducted 10 obtain comparative lield performance evaluation of direct filzration system for treating the Nile River water for domestic use. A filot plant lor this study was constructed. The pilot plant was focated in the water treatment plant of EL-Nasr Co. Ior Ferrilizer and - Shemical Industries at Talkha, Dakahlia. The pilot plant consisted of a coarse media lilter lollowed by a dual media filter.

In this study, several varlables were monitored. Some varied naturally, other variables were modifier: by the researcher and oihers were held constant through the study. Natural varjables were raw water turbidity, $\mathrm{pH}$, and tolal plankton population, Experimental variables were chemicals dosages, filtration rates and operation methods. Media types, shapes and size, and depth were held 
constant. The elfect of these variables were discussed. The result of this study showed that the Nile River water can be successfully treated under different modes of Direct Filtration.

\section{INTRODUCTION}

Direct filtration system has been employed as alternative to the conventional coagulation-flocculation-sedimentation-filtration system for treacing surface water. Direct filtration process used when raw water turbidity and color are relatively low. The main diflerence besween the two processes is that complete conventional treatment includes llocculation and sedimentation lacilites to reduce the solid's load going to filters, while direct filtration process eliminates sedimentaion (acilities in which the solids in water have to be removed by filters.

Culp (3) stated that a potential saving up to $30 \%$ of the capital costs may be realized. He also points out that direct filtration accomplishes the same water treatment goals as a conventional system, but may do so ar lower costs under certain circumstance. it is, therefore, available alternative for water treatment in developing countries where lunding for municipal facilities may be low.

Several llow schemes of direcs liltration lor low turbidity surlace water have been practiced. If the flow scheme includes coagulant and/or polymer addition, rapid mixing, flocculation and filtration, the scheme is termed "Direct Filtration". II the llocculation step is absent, the llow scheme is termed "Direct In-Line Filtration". Direct filtration dose not jnclude use of separace sedimentation lacilities. When the Iiltration process consists of chemical addicion prior to a coarse media filter Iollowed by a dual or multi-media lilter, the process is called twostage direct filtration (4).

The Nile River water course and water quality were subjected 10 changes due to natural and artilicial factors (the construction of Aswan Reservoir, Edfine Barrage, the large embankment near Faraskour, and the recent complezion of Aswan High Dam). The construction of the High Dam has caused the annual autumn llood to disappear. Millions tons of suspended solid carried by wacer are being seltied upstream the High Dain, and the susnended snlids areibeinz setiled upstream the High Dam, hence, the raw water turbidity and color are become much lower than belore constructing the High Dam. The principal objective of this study was to evaluate the direce Iiltration under the Egyptian conditions. Specilically, the study was designed to determine:

1. Whether the direct liltration process can be used for treating the Nile River waler.

2. Which mode is more economic, Two-Stage Direct filtration or the Direc: In-line filtration mode?

3. The possibility of lowering the turbidicy leve! to 1.0 NTU with minimal chemical pretreatment.

\section{MATEIRIAL AND METHOD}

A pilot plant tor this study was constructed. The pilot plant was located in the water treatment plant of EL-NASR Co. for Fertilizer and chemica! Industries at Talkha, Dakahlia. The pilor plant, (Figures $1 \& 2$ ) consisted of 


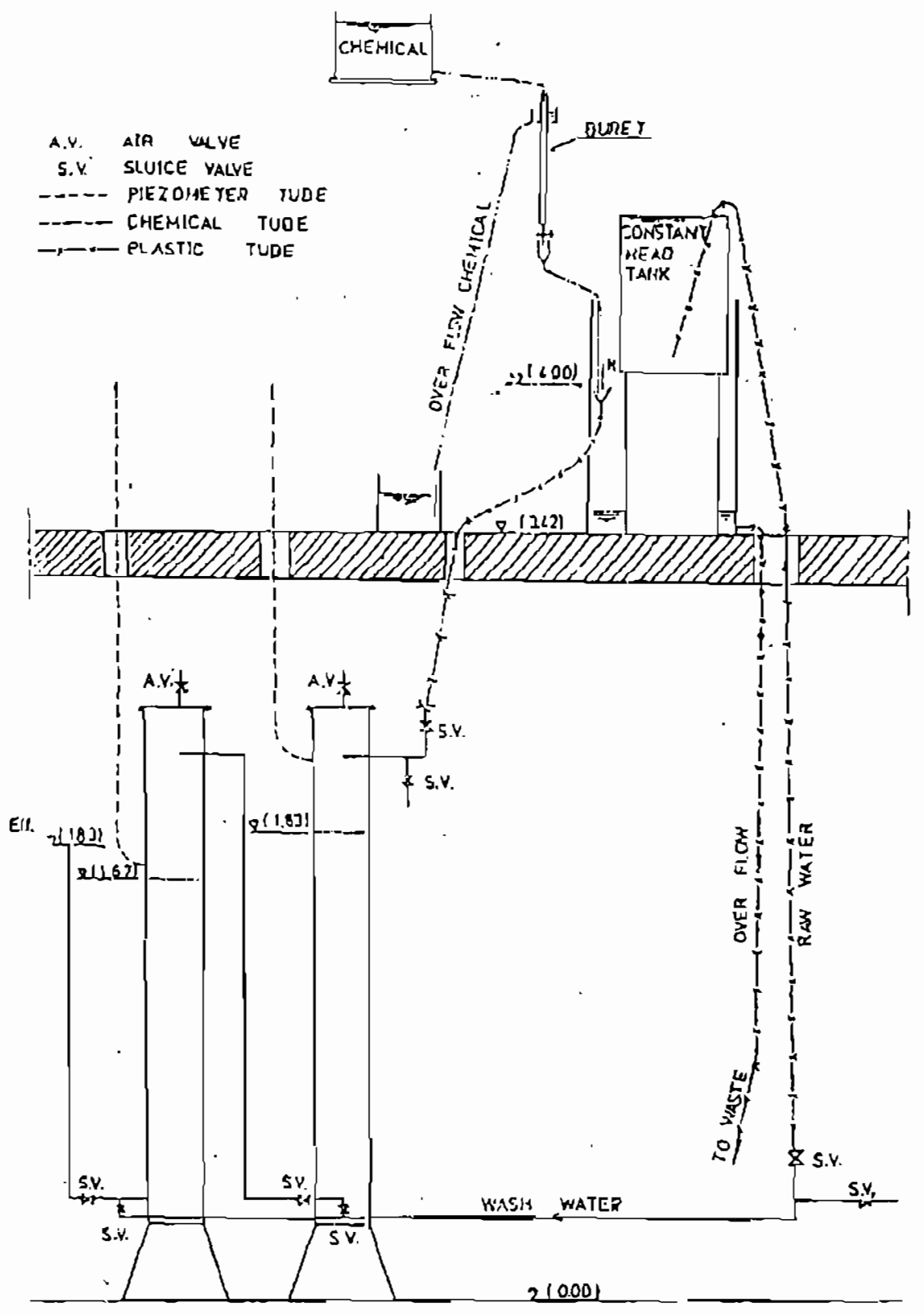

Fig. L.Schematic fluw diagran lor the pilot prant during iwo-slage direct liluration mode 


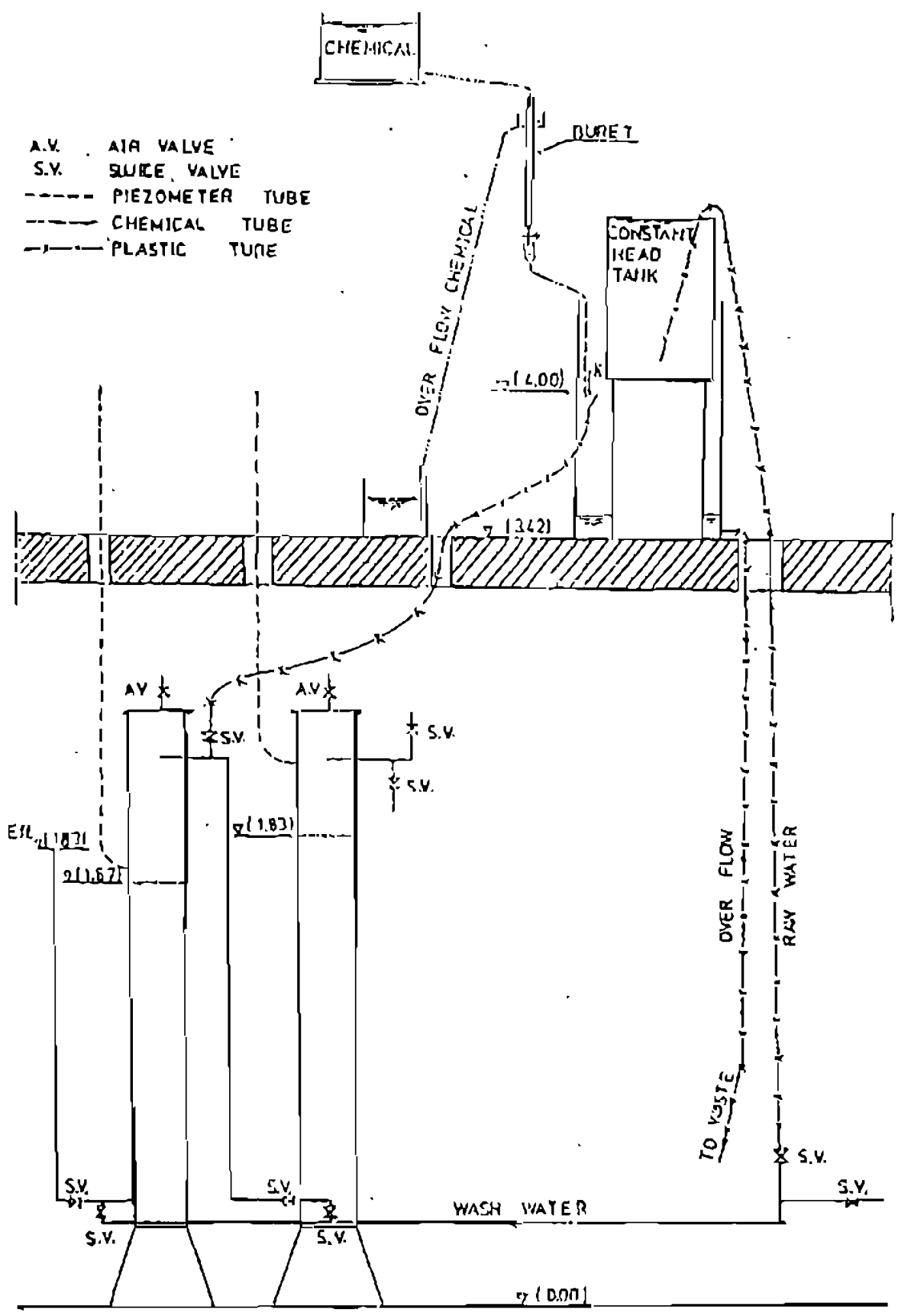

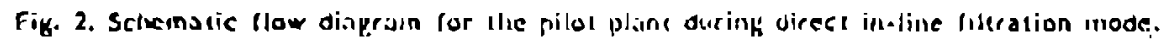


a coarse media filter Iollowed by a dual media filter.

Two steel columns having a diamerer of $20 \mathrm{~cm}$ were used to house the filter media. One column served as a clarifier (coarse media filter) and the second served as a dual media filter. The clarifier contained $130 \mathrm{~cm}$ of fine gravel having an eflective size of $3.6 \mathrm{~mm}$, uniformity coefficient of 1.9 and porosity of 0.35 . The dual media lilter contained $50 \mathrm{~cm}$ ol anthracite coal having an ellective size of $0.82 \mathrm{~mm}$, uniformity coelficient of 2.0 , and porosity of 0.42 $\mathrm{mm}$, and $30 \mathrm{~cm}$ of silica sand having an ellective size of $0.44 \mathrm{~mm}$, uniformity coetlicient of 1.55 and porosity of 0.38 .

The chemical used in this study was alum because the raw water $\mathrm{pH}$ was in the range of 7.5 to 7.8 . The percent of $\mathrm{Al}_{2}\left(\mathrm{SO}_{4}\right)_{3}$ concentration in the commercial alum was $53.35 \%$.

The PH meter was a Model $140 \mathrm{~A}$, manulactured by Fisher Accumet Insiruments, U.S.A. The turbidimeter was a Model DRT-15B, manutactured by H.F. instruments, U.S.A. . The iurbidimeter have lour ranges of NTU readings, $0-1$, $0-10,0-100$, and $0-200$.

The raw water which was used in the experimental runs was disinfected using chlorine by Talkha lactories authorities. The prechlorination dose was varied according to the working condition of the warer treatment plant. The pilot plan: was designed to be washed by raw water.

The operacions of the pilot plant were controlled by ren valves. These valves faciliated service system, backwast, and ripening modes.

Filter run breakthrough was considered to occur when the linal elfluent turbidity exceeded 1.0 NTU, or when the water level in the inlet tube reasched the top level of the injet funnel certain conditions necessitated. Both the clarifier and the filter were backwashed at the same ume before and after each run.

\section{RESULTS}

Shauban et al. (5) studied the changes in the phytoplankton community (algae) in relarion to water temperature, iransparency, chlorosity, dissolved oxygen, toral alkalinity, hardness, $\mathrm{pH}$, and nutrient salts in the Damietta Branch of the Nile River Irom Mansoura cily to the earthy dam near Faraskour. They found that the seasonal changes of temperature is one of the most important factors which control the survival and distribution of the phytoplankton population. High temperature in summer (specially June and July) is lavorable for the biooming ol Cyanophyta and some chlorophyta. They also lound that during winter the total phytoplankion is represeneed by Diatoms, of which the most prevailing species is Cyclotella Meneghiniana, being an organism developing in the cooler months.

Monthly variation of phytoplankton standing crop with its main components at Talkha station according to their studies shown in Figure 3.

According io the records of the factories laboratories at Talkha, the maximum turbidity of Nile River water in years 1987 and 1988 was $4.0 \mathrm{NTU}$, and the pH ranged Irom 7.5 to 7.8 . 
After several testing runs, twelve successful runs were conducted to examine several operation modes such as direct in-line filtration mode, and two-stage direct filtration mode with or without chemical pretreatment. Several filtration rates and chemical dosages were also examined.

Tables 1, 2, and 3 summarize the condicions of each run. Table 1 presents run date, raw and treated water characteristics of qurbidity and $\mathrm{pH}$, and run length. Table 2 presents filtration rate, head loss due to clogging only across the clarilier, the filter, and across the system, theNTU-cubic meter of turbidity removed per meter of clogging head loss for the clarilier, filter, and lor the system, and the alum dosage used in each run. Table 3 presents the head loss due to friction and clogging, and NTU-cubic meter of turbidity removed per meter ol total Iriction and clogging head loss for systern.

The rwelve runs may be classified as follows:

1 - Runs *3, 6,11 , and $* 12$ were to examine direct in-line filtration system.

2- Runs "1-4, and Runs $1-10$ were to examine two-stage direct filtration system.

3- Runs * +6 were conducted without using chemical.

4- Runs *1,*2, and Runs *7-12 were conducted by using chemica)

\section{DISCUSSION}

In this study, several variables were monitored. Some varied naturally, other variabies were modified by the researchers, and orhers were held constant through the study. Natural variables were raw water iurbidity, $\mathrm{pH}$, and total plankton population. Experimental variables were chemical dosages, liltration rates and operation methods. Media types, shapes and size, and depth were held constant. The elfect of these variables will be discussed.

Alum was used as the sol coagulant in this study; however, experimental results showed that alum as a sol coagulant was sufficient to produce filtered water with turbidily below $1.0 \mathrm{NTU}$. Alurn dosages used were in the $0.0-8.3 \mathrm{mg} / 1$ range, but most runs were conducted in the $3.5-5 \mathrm{mg} / 1$ range as $\mathrm{Al}_{2}\left(\mathrm{SO}_{4}\right)_{3}$,

The values of NTU-cubic meter of turbidity removed per meter of head loss for clarifiers and for tilters were used by Wityk, $M$. (6) to quantify the elficiencies of the clariliers and fillers for each run. The head loss due to solid accumulation was used to calculate the values of NTU-cubic meter of turbidity removed per meter of head loss, (Table 2), to make comparison among the chemical pretreatments and liltration rates of the runs.

Runs 1 and $\$ 2$, and $* 9$ and 10 (Figures 10 \& 11 ), were conducted with the same filtration rate. NTU-cubic meter of turbidity removed per meter of solid accumulation head loss of the toral system for Run 2 was greater than that for Run $* 1$, and for Run 10 was greater than that for Run 4 . The reason may be because the alum dose in Runs 2 and 10 were lower than that in Runs \#! and 9 . It is clear, from Table 2, that Runs * I have the least value of NTUcubic meter of rurbidity removed per meier of solid accumulation head loss of the total system, this may be due to the action of sweep coagulation mechanism.

in all the lollowing pairs of runs, Run *3, (Figures 4 \& 5 ) and Run *4, Run 

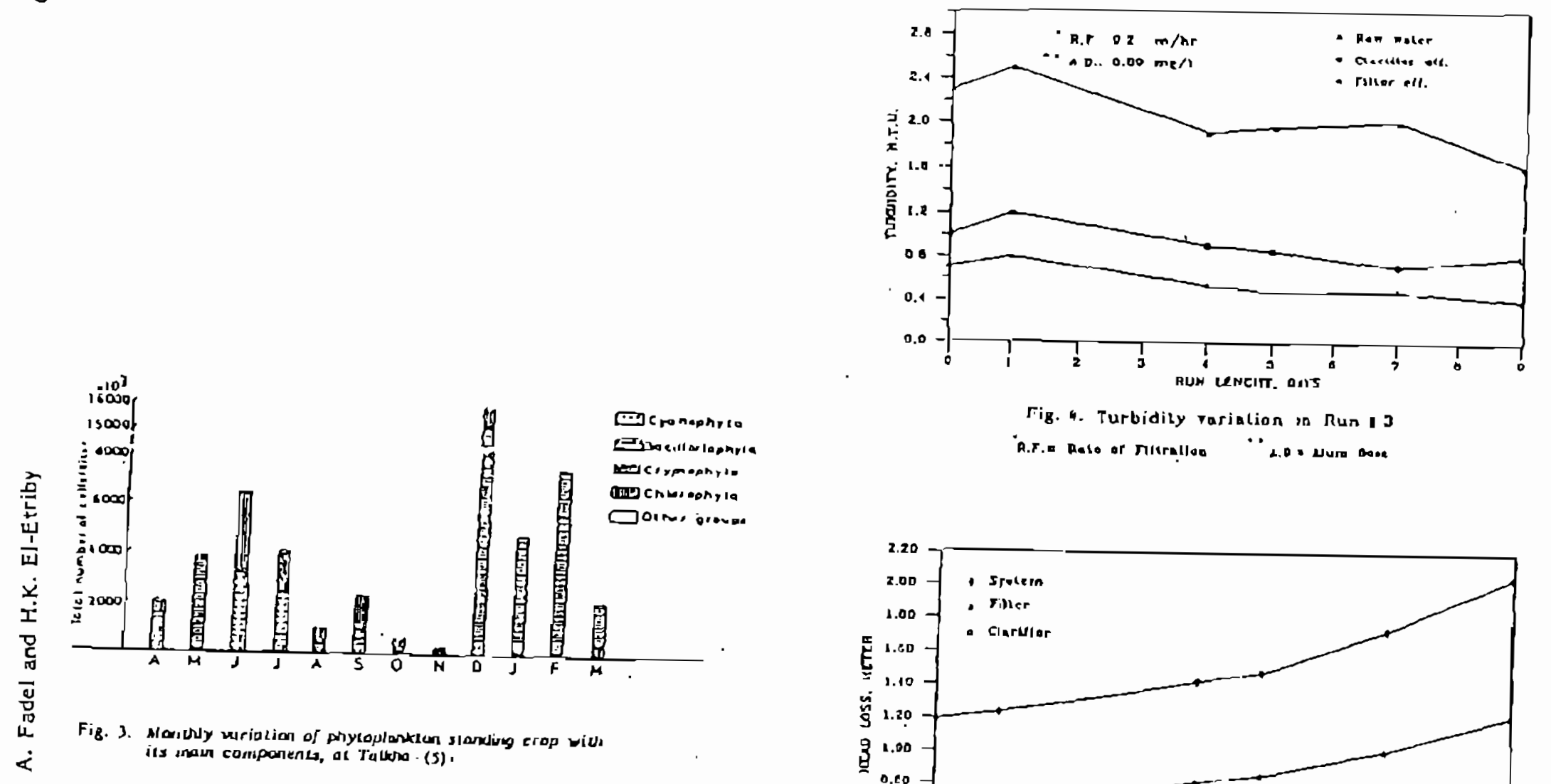

rig. 4. Turbidity rariation on Run I J

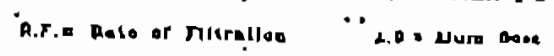

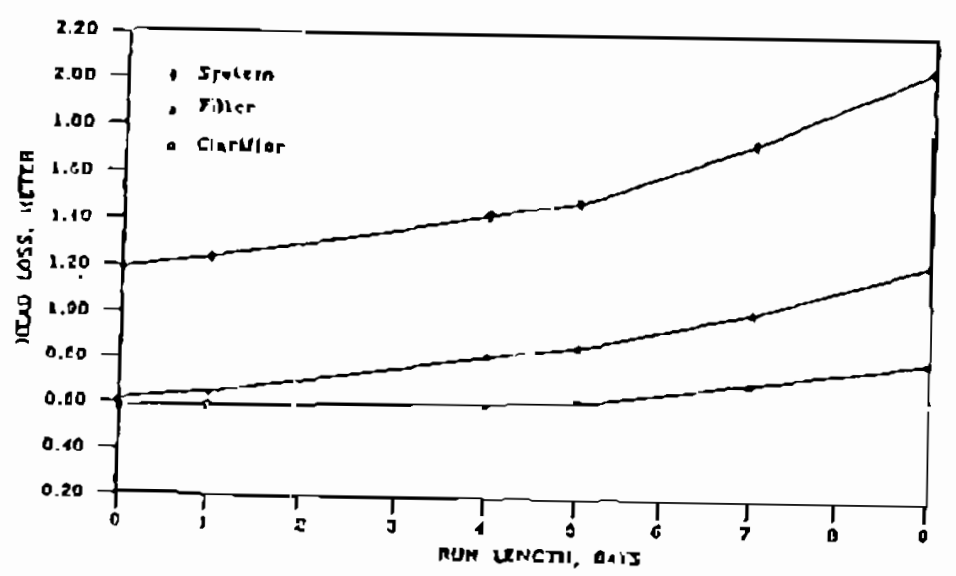

Fig. S. llead las, variation in Rup I J 
Tuble I. Run dales, rar and crealed voler characlerlecles, and run doncene

\begin{tabular}{|c|c|c|c|c|c|c|c|c|}
\hline $\begin{array}{l}\text { Run } \\
\text { Ha. }\end{array}$ & Date & $\frac{1}{\ln f}$ & $\frac{p H}{\text { ence. }}$ & 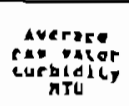 & $\begin{array}{l}\text { Lyersaze } \\
\text { clarif. } \\
\text { eff. } \\
\text { curoldisy } \\
\text { Mid }\end{array}$ & 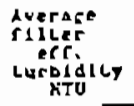 & Run 1 & lenrth \\
\hline 1 & $7 / 10 / 907$ & 7.0 & 1.J & 1.62 & 0.12 & 0.17 & 11.0 & Houry \\
\hline $\mathbf{z}$ & 13/10/987 & 7.8 & 7.5 & 1.61 & 0.13 & 0.100 & 11.0 & - \\
\hline $\mathbf{3}$ & $\begin{array}{l}20 / 10 / 3067 \\
20101007\end{array}$ & - & - & 2.05 & 0.21 & 0.98 & 0.0 & Deye \\
\hline 6 & 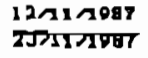 & - & - & $1.7 \mathrm{~J}$ & 0.97 & 0.00 & 13.0 & 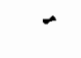 \\
\hline $\mathbf{s}$ & $\frac{16 / 1 / 1000}{28 \pi / 580}$ & - & -- & כ.9. & -- & 0.65 & 12.0 & ـ \\
\hline - & $\begin{array}{l}21 / 210 \mathrm{D} \\
\text { EJTणtr }\end{array}$ & - & - & 1,21 & - & 0.34 & 14.0 & - \\
\hline 7 & OノL2000 & 7.7 & 1.1 & 2.70 & 1.a1 & 0.09 & $\mathbf{3} .3$ & Jours \\
\hline . & S/AתDOC & 7.0 & 1.1 & 3.10 & 1. 19 & 0.10 & 32.0 & - \\
\hline$\bullet$ & $21 / 0 / 1000$ & T. 0 & T.J & 2.90 & 1.2 & 0.41 & 12.0 & - \\
\hline 10 & $23 / 4358$ & 1.9 & T. 5 & 1.00 & 1.19 & 0.49 & 21 & - \\
\hline 11 & $90 \cap 1000$ & 1.0 & 7. J & 2.75 & --- & 'Q. & 30.0 & - \\
\hline 12 & $2 \propto 0 \wedge 00$ & T. 7 & 7.4 & 1.80 & $\ldots$ & 0.85 & 14.0 & - \\
\hline
\end{tabular}

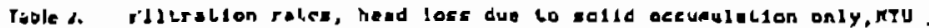
-cuble meler or curbsaly removed not meler or collo eccusulaclon head ides for cre clarifler, riller ind ror the orules, and the slum doser used in enie eluey

\begin{tabular}{|c|c|c|c|c|c|c|c|c|}
\hline $\begin{array}{l}\text { ton } \\
\text { ID. }\end{array}$ & $\begin{array}{l}\text { rigrelion } \\
\text { sice rar } \\
\text { bola clarifier } \\
\text { and rider }\end{array}$ & $\begin{array}{r}\text { Hes } \\
\text { meter } \\
\text { elar. }\end{array}$ & $\begin{array}{l}\text { d los: } \\
\text { of ill. } \\
\text { flit. }\end{array}$ & $\begin{array}{l}\text { Eater } \\
\text { syx. }\end{array}$ & $\begin{array}{l}\text { Fitu-cuode } \\
\text { Lurbidil } \\
\text { moler of } \\
\text { ciar. }\end{array}$ & $\begin{array}{l}\text { le meles } \\
\text { y remore } \\
\text { hided do }\end{array}$ & $\begin{array}{l}\text { or } \\
\text { edper } \\
\text { oxy } \\
\text { ry*. }\end{array}$ & 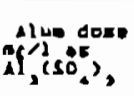 \\
\hline 1 & 0.00 & 0.36 & 0.13 & $0.7 i$ & $12 . \mathrm{B}^{\mathrm{a}}$ & 1.00 & 8.80 & A . \\
\hline 2 & 0.00 & 0.91 & 0.20 & 0.010 & 12.04 & 9.10 & 0.18 & 9.00 \\
\hline 1 & 0.20 & $0.2 \mathrm{~J}$ & $0 . \Delta 3$ & 0.00 & 300.4 & 34.60 & 100.10 & 0.00 \\
\hline 1 & 0.40 & $0 . \mathrm{JJ}$ & 0.50 & 0.74 & 107.0 & 30.12 & 123.70 & 0.00 \\
\hline 9 & 0.00 & $\longrightarrow$ & 0.71 & 0.71 & --二 & 102.00 & $100.8 \mathrm{~B}$ & 0.00 \\
\hline 0 & 0.00 & 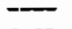 & 0.36 & 0,90 & -- & 03.89 & 53.18 & 0.00 \\
\hline 1 & $10.0=$ & 0.07 & 0.07 & 0.16 & $=6.2$ & 20.00 & סר. ב 1 & 1.00 \\
\hline 0 & 10.00 & 0.24 & 0.03 & 1,10 & 16.50 & 19.10 & 22,17 & 1.10 \\
\hline 0 & 11.00 & $0 . \Delta 7$ & כב ,ס & 0.00 & 13.50 & 0.00 & 80.70 & 9.19 \\
\hline 10 & 10.00 & 0.10 & 0.15 & 0.03 & $5: 65$ & 14.01 & 2. 112 & 3. $\Delta 0$ \\
\hline 11 & 12.20 & - & 1.00 & 1.00 & - & 19.70 & 10.20 & 3.17 \\
\hline 12 & 15.00 & $\ldots$ & 0.79 & 0.73 & - & 20.70 & 20,28 & 3.50 \\
\hline
\end{tabular}

- Sample celculetion (uelar lun 7 dalo):

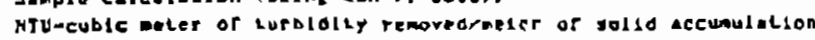

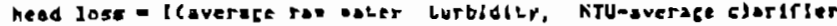
efrluent Lurbldlty, fitu) $x$ (t.r. mmr) x (buersce area or clarisler

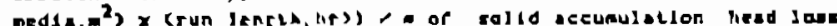
acrose the clerjiter).

$\mid\left(1.8-0.125 \times 9.0 \times \ln \times(0.1)^{2} / 1\right) \times 11.01,(0.31)=12.6$

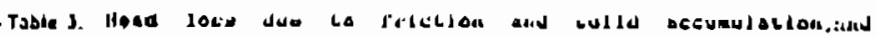

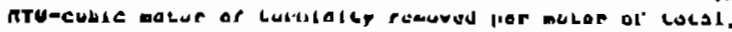

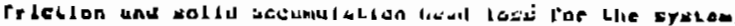

\begin{tabular}{|c|c|c|c|c|}
\hline $\begin{array}{l}\text { Lun } \\
\text { Na }\end{array}$ & 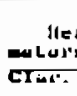 & 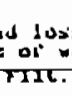 & $\frac{\text { Lur }}{\text { ayt. }}$ & 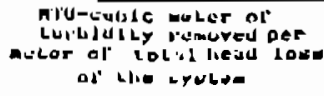 \\
\hline 1 & 0.84 & U. yo & Jע. & 2.60 \\
\hline 2 & 0.42 & 0.24 & 1. U1 & 2. 11 \\
\hline J & 0.01 & 1.21 & 2.05 & هل د. 13 \\
\hline d & 0.70 & I, 23 & (1.4) & DA. AD \\
\hline כ & -- & 1.10 & 1. Ju & د.Y. \\
\hline 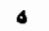 & -- & 1,10 & 1.210 & קנ. ג' \\
\hline 7 & $0 . u \downarrow$ & $0.0 \mathrm{~T}$ & 1.11 & 1.63 \\
\hline 0 & 2. OP & لנ ـ 1 & 2.0.2 & 10.23 \\
\hline 0 & ט. & $1.2 J$ & 2.61 & 3.08 \\
\hline 10 & 1.10 & U נ. 1. & 2.40 & 1.10 \\
\hline 11 & 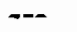 & 2.91 & هن & v. St \\
\hline 12 & -- & 2,2 & 2. 30 & A.YJ \\
\hline
\end{tabular}


$*$ and Run *6, (Figures $6 \& 7$ ) and Run $* 11$, (Figures 12 \& 13 ) and Run $* 12$, it is found that each pair had the same condition of chemical pretreatment and oseration but the run of high filtration rate had the higher value of NTU-cubic meter of turbidity removed per meter of solid accumulation head loss of the rotal system. That may be because low filtration ra:e does nor push the sirained particles through the media, hence it causes rapid clogging and rapid head oss development. Another reason may be due to the lact that larger volume of water crossed the system at high filtration rate.

Although Run -8 , (Figures 8 \& 9) was conducted with filtration rate less than that of Run $* 7$, and its alum dose was higher, thad higher value of NTU-cubie meter of turbidity removed per meter of solid accumulation head loss for the toral system than that for Run $* 7$. This may be because the majority of raw water lurbidity through Run $* 8$ might be due to algae, specially Run +8 was conducted in June, in which algac (Cyanophyra and Chlorophyta blooms (6).

The average raw warer turbidity in Runs $\$ 3-06$ was about 2.0 NTU or less and the fillered water turbidity $w a s$ in the 0.40-0.88 NTU range. In these runs, there no coagulants were used. These runs had the highests values of NTU-cubic meter of turbidity removed per mieter of solid accumulation head loss of ine total system.

When methods of reatment such as Two-stage direct filtration method and Direcr un-line flltration are compared not only the head loss due to solid accumulation should be considered in the calculation of the NTU-cubic meter of turbidity removed per meter of head loss but also all the other kinds of losses should be considered, (Table 3). In Runs *3 - *6, Run *5, which was conducred by using the direct in-line. filtration system, had the highest value of NTU-cubic meter of turbidity ramovedper meter of total head loss, this was due to the lact that frication losses of the clarifier (pipes, media, and underdrainage system) were saved in comparison :o Runs 3 and 4 . Run 16 had value of NTU-cubic meler of turbidity removed per meter of total head loss less than that of Run *5; that may be due 10 the lower filtration rate used in Run $\rightarrow 6$.

Run *11, which was conducted by using Direct in-line liltration system, had the highest value of NTU-cubic meter of turbidity removed per meter of lotal. head loss in all runs with chemical, with the exception of Run 8 , which conducted during the month of algae blooming.

The NTU-cubic meter of turbidity removed per meter of solid accumulation of head loss value for the total systern of Run 12 was greater than that value of Run "11, (Table 2); bul the value of NTU-cubic meter of iurbidity removed per meter of fricrion and solid accumulation head loss for Run *12 was smaller than value of Run 11 , (Table 3). That was because the friction head loss, across pipes and underdrainage system, is proportional to square of flow rate (2); and increasing filtration rate in Run 12 increased the triction head loss more than in Run : 11 . However, it hydraulic design or the underdrainage system, and connecting pipes was properly designed to reduce the effect of high flow rate; high values of NTU cubic meter of turbidity eemoved per meter of total hesd loss could be achieved.

II the alum dosages vs. $\mathrm{pH}$ levels are locazed in the design and operation diagram proposed by Amirtharajah and Mills (I), (Figure 14), one can find thae all runs, at which alum were used with the exception of Run 1 , agreed with 

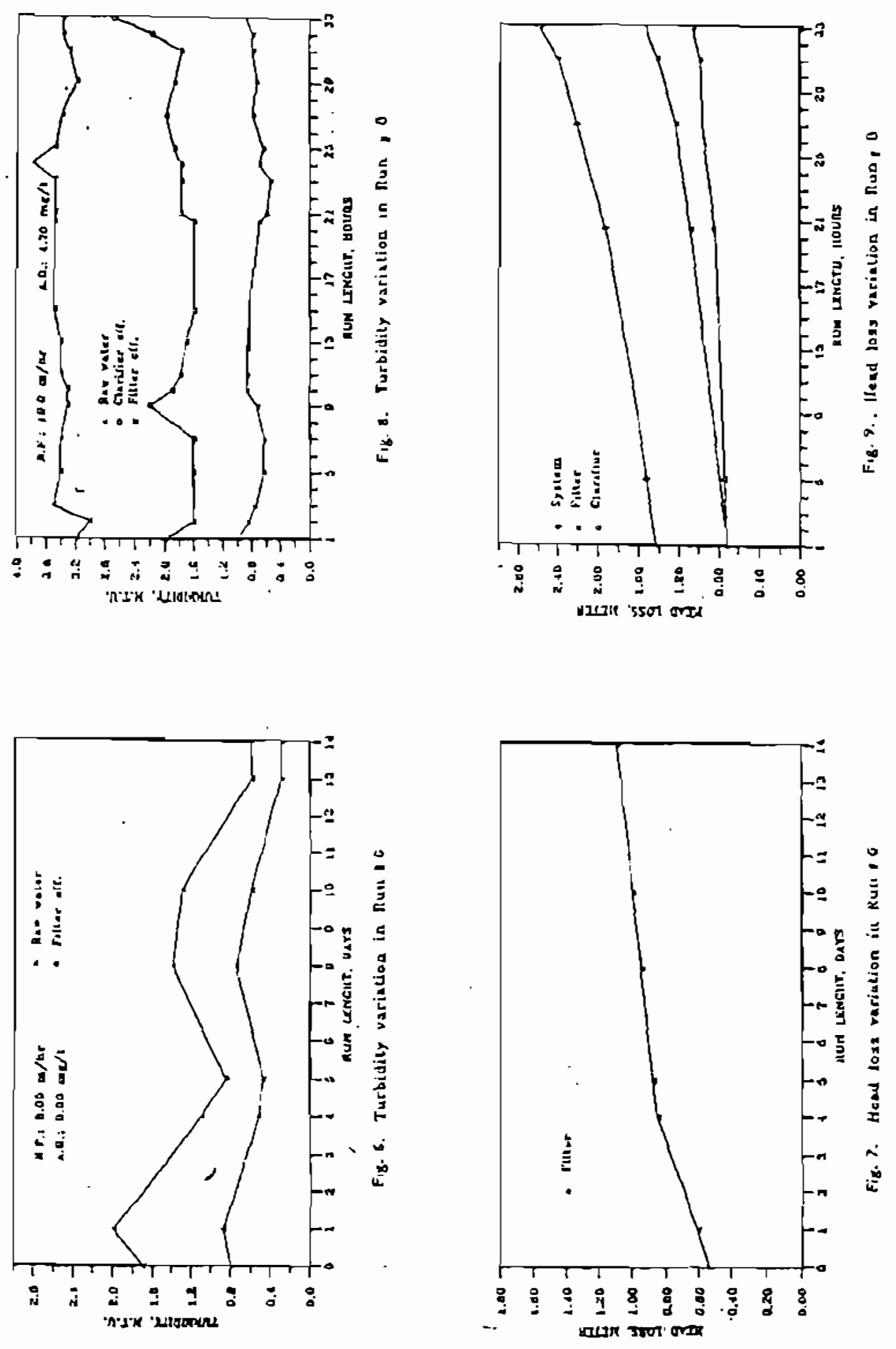

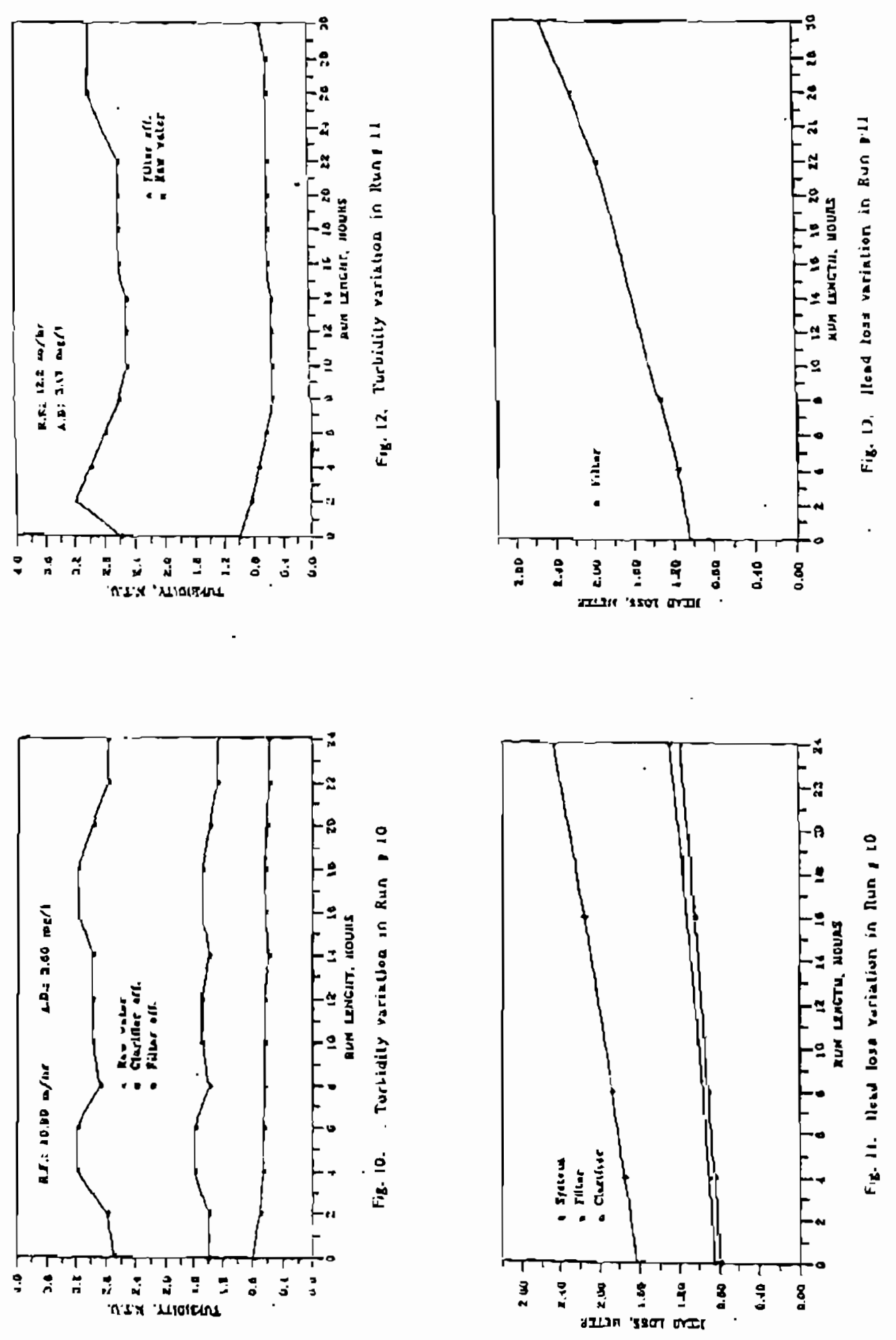


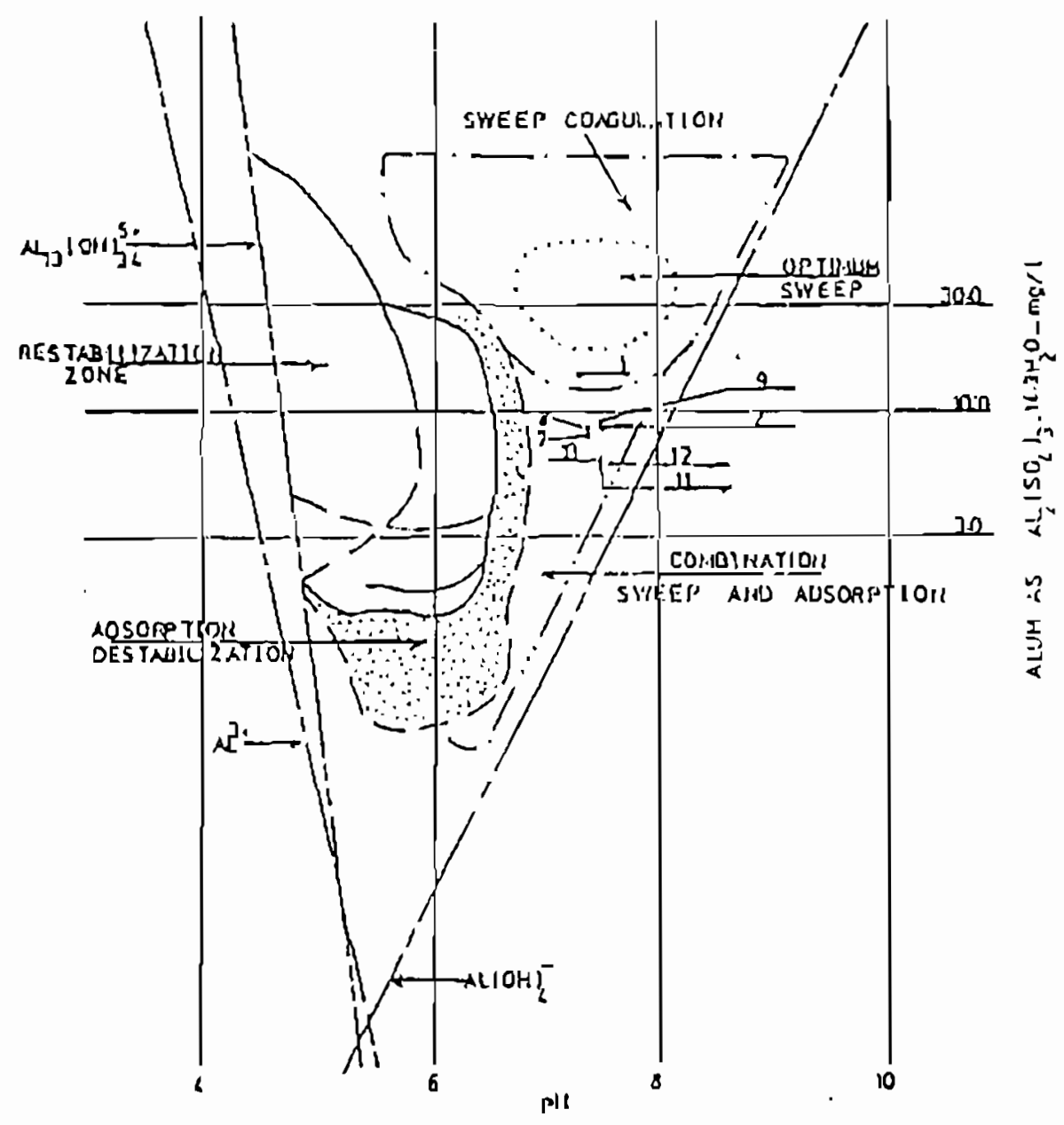

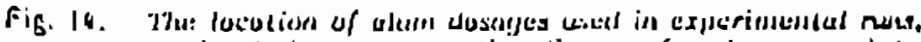

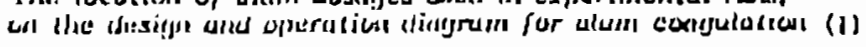


a combination of adsorption-destabilization mechanism, which discussed Dy Amirtharajah and Mills (I). It can be lound that the location of alum dose vs. pH level lor Run *l is in the sweep coagulation zone.

\section{CONCLUSIONS}

Results Irom this field study lead to the following conclusions:

1- Both, Diect In-line Fillration and Two-Stage Direct Filration system, can treat the Nile River water without using chemicals when the river water ilrbidity was less than or equal 2.0 NTU.

2- When the turbidity was less than or equal to $2.0 \mathrm{NTU}$, a run length os 9.0 days was achieved at a Iiltration rate of $9.2 \mathrm{~m} / \mathrm{hr}$ withoul the use of chemicals.

3- Alum was sulficient for treating Nlle River water. No other chemical was required or tested.

4- During the period of algae blooming, alum feed race as low as $4.7 \mathrm{mg} / \mathrm{l}$ (as $\left.\mathrm{Ai}_{2}\left(\mathrm{SO}_{4}\right)_{3}\right)$ was cosistently able 10 produce filtered water turbidity below $1.0^{2}$ NTU. On the other hand, treatment without chemical was not successiul during such period.

3. Direct In line Filtration sysiem successtully treated the Nile Fiver water montored in this study at liltration rate as nigh as $19 \mathrm{~m} / \mathrm{hr}$.

6- The coarse and dual mediae in the Two-Stage Direet Filtration system treated the Nile River water more elfectively than the dual media alone at the Direc: in-line Filtration system.

\section{RES'ERENCES}

I. Amirtharajah, A., and K.M. Mills. "Rapid-Mix Desizn lor mechanıms of Alum Coagulation." Journal of the American Vater Works Association, 74 (1982), 210-216.

2. Baumann, E.R. "Granular-Media Ceep-bed Filtration. "In water Trearment Planl Design. Ed. R. L. Sanks. Ann Arbbor: Ann Arbor Sciene, 1979.

3. Culp, R.L. "Direct Filtration. "Journal of the American Water Worxs Associa(ion, 69 (1977), 375-378.

4. Peterson, M.A., and E.R. Baumann. "Direct Filtration ol Warer." Environmental Progress, 2, No. 1 (1988), 74-80.

3. Shaaban, S., and Baka, Z. "Seasonal Changes in the Phyrolankron 5 randing Crop Relating to Some Physical and Cnemical Factors in Damietra Branch of the River Nile" Mansoura 5ci. Bull. Vol. 12 No. (1), 1985.

6. Whryk, M.S. "Direct Series Filtration of Skunk River Warer" M.5. thesis. Library, lowa Slate University, Ames, Iowa, 1985.

7. Hoham El-Etriby "Using Direct Filtration lor Water Treatment Under the Egyptian Condition". M.S. Thesis, El-Mansoura Univ., Feb., 1989. 